\title{
Impact of climate change on railway operation and maintenance in Sweden: A State-of-the-art review
}

\author{
Adithya Thaduri', Amir Garmabaki², Uday Kumar ${ }^{3}$ \\ Division of Operation and Maintenance Engineering, Luleå University of Technology, Luleå, Sweden \\ ${ }^{1}$ Corresponding author \\ E-mail: 19dithya.thaduri@ltu.se, ${ }^{2}$ amir.garmabaki@ltu.se, ${ }^{3}$ uday.kumar@ltu.se
}

Received 28 June 2021; accepted 3 August 2021

DOI https://doi.org/10.21595/mrcm.2021.22136

Check for updates

Copyright $(\subset 2021$ Adithya Thaduri, et al. This is an open access article distributed under the Creative Commons Attribution License, which permits unrestricted use, distribution, and reproduction in any medium, provided the original work is properly cited.

\begin{abstract}
Increased intensity and frequency of extreme weather conditions caused by climate change can have a negative impact on rail service performance and also increases total ownership costs. Research has shown that adverse weather conditions are responsible for 5 to $10 \%$ of total failures and $60 \%$ of delays on the railway infrastructure in Sweden. The impact of short-term and long-term effects of climate change and extreme weather events depends on the design characteristics of the railway assets, geographical location, operational profile, maturity of the climate adaptation, etc. These extreme events will have major consequences such as traffic disruption, accidents, and higher maintenance costs during the operation and maintenance (O\&M) phase. Therefore, a detailed assessment of the effects of climate change on the O\&M phase requires a more comprehensive review of the previous studies reported from different parts of the world. The paper provides a state-of-the-art review of the effects of extreme weather events and their impacts on the operation and maintenance of railway infrastructure. This paper also provides a list of vulnerable railway assets that can have an impact due to extreme weather events.
\end{abstract}

Keywords: climate change, extreme weather events, railway infrastructure, operation and maintenance, Sweden.

\section{Introduction}

The current variability in climate poses a major challenge for the operation and maintenance of transportation infrastructure. In several countries, transportation systems are vulnerable to different extreme weather extremes, such as temperature changes, rainfall, thunder, high winds, poor visibility, sea-level rise, etc. [1], [2].

In the recent past, climate change and its impact on society have been the major focus of government policies and political programs all over the world. Many industries and organizations have also commenced numerous endeavors to evaluate the impacts of climate change on transportation infrastructure concerning their business goals. The developed climate change models showed that the mean annual temperature of the Earth will probably increase by $1^{\circ}$ to $5.5^{\circ} \mathrm{C}$. In addition, annual rainfall is expected to rise in the northern hemisphere and decline in the southern hemisphere [3]. Furthermore, daily rainfall intensity and the likelihood of extreme rains can rise in each region.

Climate change endangers and jeopardizes the basic aspects of day-to-day life for people around the world and further impacts the accessibility to basic amenities such as food, health, water, and use of both land and the environment [4]. An increase in extreme weather events such as temperature, humidity, winds, rainfall, sea level, and storm rises will have a substantial impact not only on transportation infrastructure but also on other connected infrastructures.

Some of the known impacts to the transportation systems are traffic disruption due to floods, heavy snow, and rains, conditions for driving that make it difficult for travelers, drainage overflow, increased precipitation because of flooded bridges, accumulation of water on the coastal roads due to adjacent sea level rise, and blockage of roads due to landslides [5].

Furthermore, climate change has affected the sustainability of the transport sector due to an 
increase in carbon emissions from vehicles. Humphrey [6] has evaluated the various impacts of climate change and emissions on transport in several developed countries. These findings indicated that climate change can have substantial impacts on all the life cycle phases of the transport system [7].

Several past studies and ongoing research projects are progessing to evaluate the impact of climate change on railway infrastructure [8]-[13], one of the most important transportation infrastructure. Most of these studies recommend that due to climate change, the infrastructure owners need to reevaluate the policies and methodologies to be adapted during various life cycle stages of infrastructure such as design, operation, maintenance, and decommissioning. In addition, there is a need for framing new and updated rules and procedures for the design of infrastructure that can be executed to reduce the impact of climate change. However, the results of these studies are not being implemented by the railway stakeholders due to several reasons such as knowledge and awareness about climate change, lack of capital, lack of resources and time, short-term vision in planning, etc. Furthermore, it is difficult to realize the impacts of climate change because it varies with geographical locations, long-term effects, frequency of extreme weather events, and unavailability of data on consequences. Hence, to design and develop an effective strategy to deal with climate change, a comprehensive analysis is essential by considering local climate conditions, possible impacts of climate change, stakeholder's involvement, and infrastructure variations during the operation and maintenance phase [14].

The climate adaptation procedures mainly depend upon the severity and occurrence of extreme weather events, the magnitude of consequences, geographical locations, and topographical landscape. The implementation of a climate adaptation strategy requires huge investments. To plan for spending these investments, it is essential to conduct an infrastructure vulnerability assessment of extreme weather events and their corresponding consequences during the O\&M phase.

Koetse and Rietveld [15] have widely examined the literature on climate change on railways and recommended that most of the studies concentrated on short-term impacts and the transport sector have not gotten much attention from infrastructure owners. The possible impacts listed are safety and congestion of traffic on railways by heavy precipitation, frequent delays in rail transport, the tree falls due to higher winds and visibility that could affect safety and delay for rail transport, low and high-water levels affect the ground.

Meyer [16] has explored changes in design and engineering methods caused by climate changes in the United States (US). He claims that the existing design standards that were developed five decades ago are no longer applicable in the real case scenario because of changes in operating and environment context that rapidly changed in the last decade. He recommended that the ongoing and future projects must focus on highly vulnerable locations with precision standards and emphasizes the need to reassess the US highway standards and compose new and improved design, operation, and maintenance standards to tackle future climate conditions.

Dasgupta, et al. [17] studied the impact of sea-level rise in the coastal area throughout the world. This study focuses on population and infrastructure planning and recommended that the planning needs to consider all future associated risks from climate change. In addition, they proposed necessary measures to reduce the coastal impact on vulnerable areas in and around while planning for climate adaptation of infrastructure [7], [18].

Recently, Belusic [19] studied the impact of climate change on the railway sector as railways networks can act as an important driver for the future transportation mode. They recommended that everyone need to be aware of the ongoing effects of climate variations and accordingly policies need to be strategized by climate adaptation for future development and growth. Lee [20] also questioned the Intergovernmental Panel on Climate Change (IPCC) guidelines for evaluating climate change impacts and adaptation risk assessment of human-induced climate change, impacts, and position preventive decisions to reduce the impact.

To understand the impact of climate change on railway infrastructure, it is important to identify the various extreme weather events from various countries and their effect on vulnerable assets 
within railway infrastructure. Being Sweden can also have climate impact, it is also needed to identify potential failure modes that could disrupt operation and maintenance in Swedish railway infrastructure. Hence, the paper conducts a state-of-the-art review of summarizing these studies and provides strategies for climate adaptation of railway infrastructure.

The structure of the paper is summarized: Section 2 provides an overview of previous studies from different parts of the world, Section 3 provides a background of various extreme weather events, Section 4 provides a summary of various vulnerable railway assets and potential failure modes on railway infrastructure and Section 5 provides a brief overview of climate adaptation for future operation and maintenance of railway infrastructure.

\section{An overview of climate change impacts on railways from different parts of the world}

\subsection{Canada}

Due to the geographical location of Canada, it has been subjected to various extreme weather events. These events have had significant impacts on the operation and maintenance of railway infrastructure in terms of traffic disruption, accidents, and an increase in maintenance costs. Temperature increase in summer and further recurrent freeze-thaw cycle during winter would rise destruction to ground results in a surge in maintenance intervention costs [21]. Mills [22] assessed that there is higher confidence in the increased effect of permafrost, sea-level rise, storm surge, and lower confidence in landslide/avalanche impacts on mobility and maintenance of railway infrastructure. Nevertheless, sea-level rise can also have a compounding effect on bridges and drainage systems surrounding railway infrastructure. Canada may have some optimistic impacts due to decreased amount of snow and ice due to climate change though, design and construction adaption procedures may be expensive [23].

\subsection{United Kingdom}

Diaz-Neto [24] has analyzed three different climate change scenarios at 2020, 2050, and 2080 and identified that there would be an increase in flooding risk from rivers and sea-level led to inadequate drainage conditions that could lead to an increase in the deterioration of railway infrastructure. The study further concluded that there is a need to consider the climate change impacts during the planning of maintenance and renewal actions, especially at vulnerable geographical locations. In addition, it was emphasized that there is a need to improve the knowledge and awareness of climate change impacts on railway systems within infrastructure managers, experts, related stakeholders, etc. It was recommended to revise the technical standards and policies to adapt the infrastructure to climate change by modifying design guidelines during construction and appropriately conduct research studies to solve problems for future needs. Necessitate emergency and contingency plans will also be needed to be adopted to handle extreme weather events and their impacts.

The United Kingdom has commenced creating a transport roadmap for climate change adaptation. They emphasized that the transport infrastructure needs to be resilient until 2050 and allocate necessary resources to operate and maintain appropriately without additional unexpected and unwarranted costs. Furthermore, they emphasize that the level of awareness of society about climatic change impacts on railway infrastructure was not high. Hence, it was highlighted that there is a need to devise an efficient way of communication and knowledge awareness against climate change among railway stakeholders. They also recommended incorporating a risk management approach during design, operation, and maintenance considering climate change impacts and further encourage cross-modal knowledge-sharing networks [10], [13], [25], [26]. 


\subsection{United States}

Humphrey [6] has systematically analyzed the possible impacts of climate change on US railway infrastructure. This research realizes that the impact will be differed by modes of transport and will be prevalent and expensive in both social and economic provisions that will necessitate major changes in life cycle phases of the railway system. The research recommended actions, for example, integrating climate change variations into investment assessments, assimilate contingency planning and emergency response systems into transport operations, revise design standards, incorporate climate change variabilities during the planning phase and develop the new organizational framework. The research further highlighted those future costly investments and disruptions in the operations that can be reduced if the infrastructure owners would focus more on the climate change impacts on infrastructure during planning.

Another US study [27] evaluates the impact of sea-level rise globally on railway infrastructure. The estimated global sea-level rise beneath different situations ranges from $18-59 \mathrm{~cm}$. Their analysis stated that the rising sea levels in combination with the hurricanes and additional weather correlated events might cause enduring floods. This could lead to further recurrent short-term flooding of railway infrastructure and could lead to major consequences to transportation of goods and people in the US.

\subsection{Asia}

The IPCC Fourth Assessment Report foresees that global warming is well above the global mean in ranges from $2.5{ }^{\circ} \mathrm{C}$ to $4.3{ }^{\circ} \mathrm{C}$ in Asia [18]. However, these values are updated to $\left(2{ }^{\circ} \mathrm{C}\right)$ rise in the fifth assessment report [28]. Rainfall in boreal winter is expected to rise in most parts of Asia and precipitation in summer is extremely likely to rise in most parts of Asia, however, it is expected to decline in the central part of Asia. It is expected that the heat waves in summer be lengthier interval, and more severe and regular in Asia. Less too chilly days are expected as well. There is very probable to increase in the occurrence of severe rainfall events. Extreme precipitation and winds related to tropical cyclones are expected to increase in most parts of Asia. Sea levels are expected to increase from $18 \mathrm{~cm}$ to $59 \mathrm{~cm}$ from different scenarios.

Several extreme weather events in the past in Asia consist of severe floods, cyclones, and tsunamis that was a devastating impact on not only transport infrastructure but other infrastructures as well. These extreme events had harshly disrupted their operations with already existing degrading infrastructure and a further burden on them due to an increase in population and higher temperature ranges. The damage prone to transport infrastructure in Bangladesh by 2007 floods was approximately 34 \% (the US \$ 363 million). The Aceh Flood 2007 in Indonesia impacted substantial destruction to the transportation system lead to the US \$ 35 million that is approximately $25 \%$ of infrastructure costs [7].

\section{Extreme weather events in Sweden}

Climate change influences the entire climate system that indicates changes for both average temperature and rainfall, sea-level rise, increase in vegetation, floods, and droughts, etc. It is a complicated and convoluted system needing a detailed understanding of feedback processes and interfaces for the creation of the climate models [29].

In Sweden, historically experience some extreme weather and climate events such as dangerous droughts, storms, and heatwaves. Though there were comparatively less extreme weather events, there will be an increase in severity, occurrence, and duration of these events due to change in operating conditions, extreme $\mathrm{CO} 2$ emissions, and other factors. For instance, a rise in average temperature by $4{ }^{\circ} \mathrm{C}$ should not imply that it is merely uniformly warmer than earlier. The temperature thus could also shift by experiencing a larger variability, wherever that formerly was extreme weather befalls more frequent. These variations in the properties of extreme weather 
events can be connected to these three variations of the distribution [29], [30].

Sweden was affected with the most terrible water scarcity in the south-east in around 100 years in the summer of 2017 after 2 years of abnormally low rainfall. In Sweden, the Swedish Meteorological and Hydrological Institute (SMHI) is responsible for analyzing various climatic properties to endeavor for better public wellbeing policies, improved safety, and provide sustainable society. They operate with weather forecasts and early warnings, conduct research and development, measure and analyze observations and climate data analyses for further research. The major climate parameters that are of interest in Sweden are temperature, zero-crossings, windstorm, snow, floods, and rainfall. These are described below.

\subsection{Temperature}

According to Klimatanpassning [31], the average global temperature is expected to increase between $0.5^{\circ} \mathrm{C}$ to $5^{\circ} \mathrm{C}$ by the year 2100 . Marginally higher warming up than the global average and it is likened through a similar period.

The regional climate scenarios customized for Sweden, centered on global climate scenarios RCP4.5 and RCP8.5, showed that the annual mean temperature of Sweden will increase by $2{ }^{\circ} \mathrm{C}$ to $7{ }^{\circ} \mathrm{C}$ in the time $2071-2100$ when contrasted to the mention time 1961-1990. The highest temperature rise is highly likely to be through the winter, amid $2{ }^{\circ} \mathrm{C}$ and $9{ }^{\circ} \mathrm{C}$ by the ending of the period. In summer, changes are projected to be a smaller amount than compared to winter, amid $1{ }^{\circ} \mathrm{C}$ and $6{ }^{\circ} \mathrm{C}$ hotter. These variations are affected by substantial regional disparities with the highest effect in the northern part of Sweden.

The overall duration of the growing season (number of days once the average daily temperature is over $5{ }^{\circ} \mathrm{C}$ for a specific period) is likely to increase by $1-2$ months all over Sweden, apart from the south where there will be an increase that is projected to be up to 3 months. A greater mean temperature of $5{ }^{\circ} \mathrm{C}$ implies that Sundsvall (north of Sweden) in the future will have a similar average temperature as of today in Stockholm.

Average temperature, the occurrence of several days with temperatures in particular periods, and the duration of the extremes are the major important factors for natural systems and society. A soaring mean temperature affects steady changes, much for temperature extremes in means of both their range and frequency.

In addition to the temperature variation, uncertainties from internal variability must be also considered for climate adaptation activities by railway stakeholders and decision-makers from the government [32].

\subsection{Zero crossings}

If the temperature frequently changes around $0{ }^{\circ} \mathrm{C}$, it influences areas such as transport and farming. The word 'zero crossings' defines the number of days with the change of temperature. A day with zero crossing is identified "as a day with temperature both below $0{ }^{\circ} \mathrm{C}$ and above $0{ }^{\circ} \mathrm{C}$ calculated from two meters above the ground" [31].

Zero crossings are extremely frequent in the central part of Sweden with a mean of 100-120 days per year. The minimum number of zero crossings arises in the southern part of Sweden. Usually, the number of zero crossings is larger throughout spring, although they are as common as throughout equally winter and autumn. During the summer, the trend happens rarely in all areas of the country.

According to SMHI's latest estimated climate scenarios, where zero crossings have exclusively been analyzed, the findings showed a reduction in amount all over the country throughout spring and autumn. In the winter, the total amount of days with zero crossings will reduce in the southern part of Sweden however there will be a rise in northern and central parts of Sweden [31]. 


\subsection{Windstorm}

Due to the complexity of the windstorm occurrence, climate scenarios analyst was not able to provide proper estimates on how wind climate might change in the future. Some many intricate factors and conditions affect the course of event, intensity, and occurrence of these storms. For example, a warmer ocean surface and consist of above water vapor present in the environment could impact the origination of storms.

At a similar moment, ocean warming could lead to decreased variations involving both cold and warm air masses, which might perform an essential role in the origination of severe storms. This might in sequence neutralize by the increasing influence that warming up has on the development of the storm. The low-pressure systems that can grow into these storms are usually projected to turn into less frequent in the northern hemisphere during warmer climate. It is hard to derive suppositions from the various scenarios about regional changes that surpass irregularity naturally happening in the system.

Weaker winters with higher rainfall are projected to grow to be more frequent in future, and steadily the circumstances for soil frost will alter. Consequently, the possible risk of damage due to storm might rise irrespective of variations in the wind climate. The magnitude of the destruction also differs on other aspects that are usually associated with behavior of human and susceptibility to traffic disruptions in the infrastructure, further dependency on electricity [31].

\subsection{Snow}

Sweden is a sizable country with huge discrepancies in temperature and rainfall. This is particularly evident by studying the extent of snow cover. Due to climate change, the duration of snow cover is likely to decline. Huge volumes of snow can affect key disruptions in traffic, destruction to buildings, trees, and overhead power lines. The difficulties tend to get harsher in combination with fierce winds or if the snow is further damp and heavy.

The quantity of water that is required in the snow cover throughout the winter and by that melt in the spring, disturbs the overflow of our watercourses in various seasons. When a heavy snow cover melts quickly, triggering a bigger flood in spring. Snow cover can also facilitate chances for leisure for, example skiing sports after the snow cover is dense and long-lasting.

In the mountain valleys situated in the northern part of Sweden, the first snow cover usually develops at the beginning of October. In mountains, this occurs mostly in September. There is an explanation of why coastal areas typically consist of tiny amounts of snow in early winter is because the temperature is comparatively extreme throughout autumn and near the beginning of winter across coastal areas and lakes.

It may take a long time before a further enduring snow cover is created, particularly in the southern part of Sweden. The snow cover could not persist during the winter from the central part of Sweden, Värmland, via the south of Dalarna and to central Gästrikland. Due to climate change, the snow cover period is likely to reduce, and in southern Sweden where there is expected to be no way of enduring snow cover in any way [31].

\subsection{Floods}

In the future, floods will grow to be more frequent all along the southern coast of Sweden, due to increasing sea levels. For lakes and streams, the risks differ throughout the country, where several parts are likely to have a higher risk of flooding and others are lesser at risk. The fundamental causes will vary depending on where the flooding happens near the coasts, rivers, and lakes or mostly in cities.

The risk of flooding in lakes and waterways might change over in the future but fluctuates among various parts of the country. The risk of flooding is also relying on additional aspects such as how watercourses are controlled, what preventive methods are implemented, and how 
infrastructure will vary over time because of replacements and renewals.

Severe precipitation through a brief period can create flooding in cities and transport infrastructure. In urban areas, overflow frequently happens from small areas with excessive amounts of impermeable surfaces, that cannot absorb any water. Stormwater systems hence must manage a larger part of the rainfall which it fails could affect the beneath the surface of infrastructure. Research into severe precipitation in a future climate indicates that this type of event is projected to develop more commonly in the future due to bad planning, congestion, and over usage of stormwater. Climate change adaptation attempts need to be prepared to build up resilience to severe precipitation in urban areas [31]. In addition, it is reported that in several areas' railway embankments can act as a dam in the occurrence of extreme precipitation due to capacity and /or poor maintenance of drainage system [33].

\section{Climate change impact on Swedish railways infrastructure}

Changing climate will impact Sweden's transport network due to increased risk of extreme precipitation, landslides, erosion, and level changes in seas, etc. [34]. It is studied that railway infrastructure will be both affected by the risk of flooding, landslides, higher winds, and in addition to railway bridges that are susceptible to extreme weather events [35]. All through heatwaves, railway transport is difficult to operate due to the higher tolerance of heat in technical components and cooling systems [19]. Hence, there is a need to consider climate change parameters when planning of new construction of a transport network. In addition, the climate adaptation strategy aims to reduce the climatic impacts by reviewing and adapting existing infrastructure.

As increasingly intense rainfall is expected in the future, accidents due to heavy rainfall may become more common. To reduce the risk of floods and flushes, well-thought-out stormwater management is needed. The railway network is also affected by rising sea levels. Low-lying rails and bridges can be flooded and become unusable for shorter or longer periods. Some parts of the rail network are already at risk of coastal flooding and beach erosion.

Traffic jams can also be happened by fallen trees. Problems with fallen trees are often linked to windstorms. But changes in groundwater levels, soil moisture, and precipitation patterns can also make it easier for trees to fall in intense winds. These climate changes also lead to an increased risk of landslides and avalanches. Railway tracks can disappear in the event of landslides or be blocked by fallen stones, blocks, and trees.

Longer periods of heat waves are expected to increase, and these can disrupt railway operations. Rails, components in switches, and overhead lines can expand in heat and can cause traffic disruptions. If this heat exceeds the design limits, then there will be an increase in the probability of occurrence of rail defects. Heat and drought also increase the risk of vegetation fires and thus also the need to stop or redirect traffic.

Climate change is leading to shorter and warmer winters, which in turn can lead to a reduced amount of snow. The variation in climate also causes changes in the number of zero crossings. This can lead to increased problems with slippery railway conditions, rail buckling, and frost bursts. With rising average temperatures, ice formation on lakes and seas is expected to decrease.

The consequences of changing precipitation patterns and levels in seas, lakes, streams, and groundwater need to be kept in mind when planning and building new railway infrastructure. The changing climate also means that the need for maintenance and upkeep of railways can change. An important part of climate adaptation is to identify vulnerable railway assets, risks that arise on the existing railway network and develop adaptation measures to reduce its impact.

\subsection{Impact of extreme weather events on vulnerable railway assets}

Fig. 1 [36] provides an interrelation between failure causes of extreme weather events on railway infrastructure failure modes, consequences, and failure effects. It was observed that these extreme weather events could disrupt and affect essential functions of the railway transport infrastructure. 


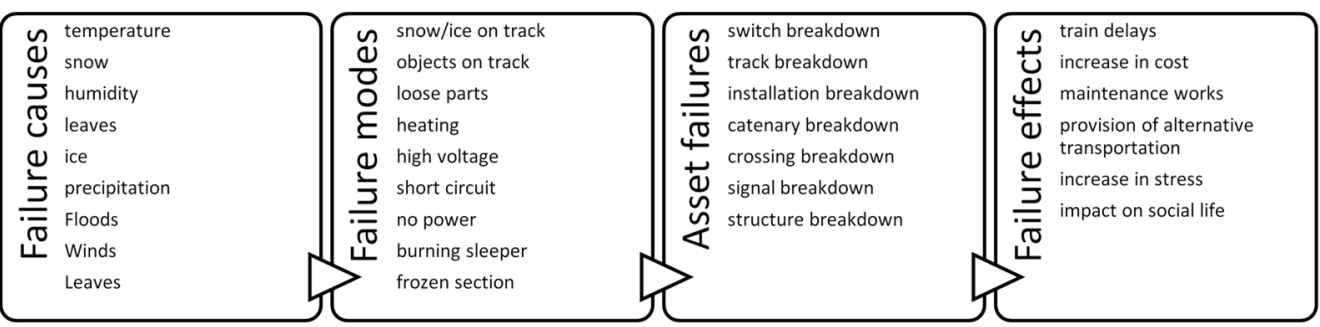

Fig. 1. Failure causes, failure modes, asset failures, and failure effects on rail infrastructure

All railway infrastructure components such as tracks, catenary, bridges, embankments, tracks, etc., are impacted by extreme weather events. In some cases, such as track, the higher temperatures/lower temperatures, precipitation, and snowstorm could lead to traffic disruptions and in the worst cases lead to damage to the track. However, in some of the cases such as permafrost and zero-crossing, it is hard to measure the impact of these events on railway infrastructure. Hence, a suitable understanding of weather events during the plan, design, operation, and maintenance of railway infrastructure is to be assessed to increase the serviceability and life of the assets. Provided that the railway transportation infrastructure is the backbone drive of the economy of the country, it is necessary to assess these impacts for further organizing of standards and policies and allocate sufficient funding to improve the resilience of the transportation sector [7]. Table 1 reported the impact matrix among the various vulnerable components in infrastructure and its impact on climate events.

The potential impacts on the infrastructure and railway operation and maintenance depending upon the severity and occurrence of an event. It also needed to consider several other recommended actions such as increase in inspection, reduction in operating speeds, risk assessment of effects of climate change can be adopted to mitigate the risk and its failures. These failures can lead to having a compounding effect socially such as inconvenience, economic losses due to disruptions, and an increase in carbon emissions due to additional transportation effects to reach the destination. In some cases, it might lead to serious consequences such as train derailments, damage to the railway infrastructure, and danger to human life. The various possible effects and their gaps in practice, knowledge, and information are tabulated in Table 2.

Table 1. Impact matrix of extreme weather events on vulnerable assets

\begin{tabular}{|c|c|c|c|c|c|c|}
\hline $\begin{array}{c}\text { Vulnerable } \\
\text { infrastructure }\end{array}$ & Bridges & $\begin{array}{c}\text { Drainage } \\
\text { systems }\end{array}$ & $\begin{array}{c}\text { Railway } \\
\text { tracks }\end{array}$ & Culverts & $\begin{array}{c}\text { Slip } \\
\text { slopes }\end{array}$ & $\begin{array}{c}\text { Coastal } \\
\text { railways }\end{array}$ \\
\hline Temperature & $\mathrm{X}$ & & $\mathrm{X}$ & & & $\mathrm{X}$ \\
\hline Snow & $\mathrm{X}$ & $\mathrm{X}$ & $\mathrm{X}$ & $\mathrm{X}$ & $\mathrm{X}$ & $\mathrm{X}$ \\
\hline Rainfall & $\mathrm{X}$ & $\mathrm{X}$ & $\mathrm{X}$ & $\mathrm{X}$ & $\mathrm{X}$ & $\mathrm{X}$ \\
\hline Wind & $\mathrm{X}$ & & & & & \\
\hline Storm/cyclone & $\mathrm{X}$ & $\mathrm{X}$ & $\mathrm{X}$ & $\mathrm{X}$ & $\mathrm{X}$ & $\mathrm{X}$ \\
\hline Sea level rise & $\mathrm{X}$ & & & & & $\mathrm{X}$ \\
\hline
\end{tabular}

Table 2. Effects of climate change on the railway network [34]

\begin{tabular}{|c|c|c|c|}
\hline $\begin{array}{c}\text { Climate change effect } \\
\text { category }\end{array}$ & Risk ranking & Vulnerable asset & $\begin{array}{c}\text { Gaps in practice, knowledge, } \\
\text { and information }\end{array}$ \\
\hline $\begin{array}{c}\text { Rainfall (including high } \\
\text { amount falls, variations to } \\
\text { mean rainfall, groundwater } \\
\text { content, and soil moisture) }\end{array}$ & High & $\begin{array}{c}\text { Track movement } \\
\text { Line closure } \\
\text { Reduced operating speeds }\end{array}$ & $\begin{array}{c}\text { Impact of rising in both } \\
\text { average and extreme rainfall } \\
\text { on groundwater content }\end{array}$ \\
\hline
\end{tabular}




\begin{tabular}{|c|c|c|c|}
\hline $\begin{array}{c}\text { Extreme high temperature } \\
\text { (including air and ground } \\
\text { temperature) }\end{array}$ & High & $\begin{array}{c}\text { Track buckling } \\
\text { Line closure } \\
\text { Reduced operating speeds }\end{array}$ & $\begin{array}{l}\text { The interrelationship between } \\
\text { temperature with other events } \\
\text { such as solar storms, land- } \\
\text { surface temperature, and } \\
\text { sudden hot days. } \\
\text { The position of high-risk } \\
\text { track segments is related to } \\
\text { forecasted incidences of high } \\
\text { temperatures } \\
\text { Track stability at elevated } \\
\text { temperatures than presently } \\
\text { faced temperature levels. }\end{array}$ \\
\hline $\begin{array}{l}\text { Flooding (including river } \\
\text { and surface flooding) }\end{array}$ & High & $\begin{array}{c}\text { Track washout } \\
\text { Line closure } \\
\text { Reduced operating speeds }\end{array}$ & $\begin{array}{l}\text { Current and future track } \\
\text { segments with below- } \\
\text { capacity drainage systems } \\
\text { studying through } 2040 \text { and } \\
2090 \text { climate scenarios } \\
\text { Assessment of Bridge scour }\end{array}$ \\
\hline $\begin{array}{l}\text { Inland erosion and } \\
\text { instability }\end{array}$ & High & $\begin{array}{l}\text { Disruptions from blockages } \\
\text { Decrease in track condition }\end{array}$ & $\begin{array}{l}\text { Assessment of Geotechnical } \\
\text { areas present in and around } \\
\text { slip locations } \\
\text { Effect of rising in both } \\
\text { average and extreme rainfall } \\
\text { on slips }\end{array}$ \\
\hline Coastal flooding & $\begin{array}{l}\text { High but } \\
\text { 'true' risk } \\
\text { maybe } \\
\text { medium }\end{array}$ & $\begin{array}{l}\text { Saltwater corrosion } \\
\text { Flooding causes line closures }\end{array}$ & $\begin{array}{c}\text { The combined effect of both } \\
\text { storm surge and sea-level rise } \\
\text { on railway assets present } \\
\text { lower levels. }\end{array}$ \\
\hline High winds & $\begin{array}{l}\text { High bar } \\
\text { 'true' risk } \\
\text { maybe } \\
\text { medium }\end{array}$ & $\begin{array}{c}\text { Rolling stock stability } \\
\text { Modest risk of railway } \\
\text { equipment and destruction } \\
\text { Decreased operating speeds }\end{array}$ & $\begin{array}{c}\text { Position and severity of gusts } \\
\text { at higher wind location in } \\
\text { connection with the national } \\
\text { railway network }\end{array}$ \\
\hline Snow and ice & $\begin{array}{l}\text { High bar } \\
\text { 'true' risk } \\
\text { maybe } \\
\text { medium }\end{array}$ & $\begin{array}{c}\text { Clogged areas form trees } \\
\text { Clearances of snow and further } \\
\text { inspections }\end{array}$ & - \\
\hline Wildfire & $\begin{array}{l}\text { High bar } \\
\text { 'true' risk } \\
\text { maybe } \\
\text { medium }\end{array}$ & $\begin{array}{c}\text { Wayside fires that effect } \\
\text { destruction to equipment } \\
\text { Vegetation }\end{array}$ & - \\
\hline Lightning & $\begin{array}{l}\text { High bar } \\
\text { 'true' risk } \\
\text { may be low }\end{array}$ & $\begin{array}{c}\text { Risk to line workers } \\
\text { Outages of power } \\
\text { Destruction to infrastructure }\end{array}$ & - \\
\hline Fog and humidity & $\begin{array}{l}\text { High but } \\
\text { 'true' risk } \\
\text { maybe } \\
\text { medium }\end{array}$ & \begin{tabular}{|c|} 
Arcing of conductive \\
components in humid situations \\
Visibility is reduced below \\
spotting of signal \\
Reduction of operating speeds
\end{tabular} & - \\
\hline Coastal erosion & Medium & $\begin{array}{l}\text { Coastal erosion threatens lines } \\
\text { Erosion of coastal defenses }\end{array}$ & Scour rates in coastal areas \\
\hline $\begin{array}{l}\text { Drought (including low } \\
\text { river flows) }\end{array}$ & Moderate & \begin{tabular}{|c|} 
Settlement of edifices and \\
surpass values of twist and cant \\
Fires occur over trackside that \\
affect destruction to equipment \\
Vegetation
\end{tabular} & \\
\hline $\begin{array}{c}\text { Fewer low-temperature } \\
\text { episodes }\end{array}$ & Moderate & Frozen points & - \\
\hline
\end{tabular}


In a study using fuzzy Bayesian approach [1], the climate results of every climate parameter of environmental factors related to UK rails were computed and ranked in Table 3.

Table 3. Results from Questionnaire for climate risk analysis conducted on UK railways [1]

\begin{tabular}{|c|c|c|}
\hline Environmental factors & Climate threat on the railway & Rank \\
\hline \multirow{4}{*}{ Temperature increase } & $\begin{array}{c}\text { A1. Track buckling affecting risk of derailment and further } \\
\text { decreased chances for maintenance on track }\end{array}$ & 6 \\
\cline { 2 - 3 } & $\begin{array}{c}\text { A2. Inaccurate signaling and power wayside systems due to } \\
\text { malfunctioning of temperature controls systems and overheating of } \\
\text { electronic circuit }\end{array}$ & 6 \\
\hline \multirow{4}{*}{$\begin{array}{c}\text { Intensive } \\
\text { rainfall/flooding }\end{array}$} & $\begin{array}{c}\text { B1. Destruction of bridge foundations, collapse and further led to } \\
\text { increase in derailment risk }\end{array}$ & 1 \\
\cline { 2 - 3 } & B2. Landslips affected barrier in rising derailment risk & 2 \\
\cline { 2 - 3 } & $\begin{array}{c}\text { B3. Heavy rainfall could reduce visibility and planned work that } \\
\text { needs is postponed because of safety reasons }\end{array}$ & 7 \\
\cline { 2 - 3 } $\begin{array}{c}\text { Increased intensity and } \\
\text { frequency of high } \\
\text { windstorms }\end{array}$ & B4. Track drainage systems clogged due to flooding of the track & 3 \\
\cline { 2 - 3 } & $\begin{array}{c}\text { C2. Falling of surrounding trees onto the track } \\
\text { n2. Higher winds that could reduce visibility and planned work that } \\
\text { needs is postponed because of safety reasons }\end{array}$ & 5 \\
\cline { 2 - 3 } C3. Structure's instability & 8 \\
\hline \multirow{2}{*}{\begin{tabular}{c} 
Sea level rise \\
\cline { 2 - 3 }
\end{tabular}} & $\begin{array}{c}\text { D1. Over flooding could lead to an increasing derailment risk } \\
\text { D2. Decrease in maintenance windows due to improper inspection } \\
\text { of bridges or sea walls }\end{array}$ & 2 \\
\hline
\end{tabular}

There exist several weather-associated effects on infrastructure functioning that vary across geographical areas. Table 4 provides an outline of the possible impacts of climate change on railway assets and their performance [36].

In addition to the above effects, several research studies were conducted on the effect of several extreme weather events on vulnerable railway assets in different countries are tabulated in Table 5. This research provides possible vulnerable assets that are relevant for the Swedish climate.

The railway needs to have safe and reliable transport and necessary to be more resilient towards effects of weather for the future. To understand these risk sites, there is a need to focus particularly on various assets of railway infrastructure which are prone to extreme weather events. Initially, to estimate the climate impacts, it is imperative to draw trends of extreme weather events in the future by considering both spatial and temporal resolution by evaluating various forecasting models. Geographic Information Systems (GIS) can also be used to assist the detection, identification, and further mapping of vulnerable areas of infrastructure [37].

To implement the climate adaptation of railway infrastructure, it is necessary to conduct a risk assessment for expected occurrences, severity, and associated consequences for the potential vulnerable assets [38]. Based on the questionnaire, interviews, and discussions from various stakeholders, they calculated risk by anticipating severity, occurrence, and consequence of each of the extreme weather events on each of the vulnerable assets.

By conducting this vulnerability analysis, the most vulnerable areas were identified as signaling, track, heating, traction systems, telecommunication systems, embankments, culverts, and bridges. This vulnerability analysis could highlight the necessity of considering both quantity and duration of effect of extreme weather events on infrastructure by understanding failures and consequences to railways to specific locations [39]. Floods have possible lesser effects compared to other extreme weather events due to exposure to only a few areas of spatial nature and specific regions of railway assets.

For climate adaptation of the railway infrastructure, it is important to consider the isolated events on the infrastructure so that necessary measures can be taken in the future to reduce its impact. Those events such as floods, landslides, and harsh winters can accommodate prolonged nature because of awareness [71], [72]. To implement these recommendary actions, revision of 
policies, standards and sufficient funding needs to be in place to accommodate these additional costs of implementation during design, operation, and maintenance. Several countries compiled reports on climate adaption for railway infrastructure such as France [73], Germany [74], United Kingdom [10], [13], [14], [42], [75], India [76], South Africa [77], Canada [23], [78], Russia [79] and Sweden [34], [80].

Table 4. Relationship between climate change impacts and consequences on railway operation and infrastructure [36]

\begin{tabular}{|c|c|c|c|}
\hline $\begin{array}{l}\text { Climate } \\
\text { factor }\end{array}$ & Possible Impacts & $\begin{array}{l}\text { Consequences to railway } \\
\text { infrastructure }\end{array}$ & $\begin{array}{c}\text { Consequences to railway } \\
\text { operations }\end{array}$ \\
\hline 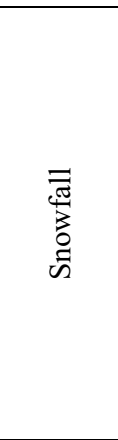 & $\begin{array}{l}\text { - Heavy floods } \\
\text { - Increase in freezing } \\
\text { - Destruction to power } \\
\text { cables } \\
\text { - Damage to } \\
\text { electricity } \\
\text { - Blowing of snow } \\
\text { - Blockage of tracks }\end{array}$ & $\begin{array}{l}\text { - Destruction to railway } \\
\text { embankments and culverts } \\
\text { - Less support to bridge } \\
\text { scour } \\
\text { - Increase in water content } \\
\text { on track } \\
\text { Increase in vegetation } \\
\text { - Destruction to railway } \\
\text { track } \\
\text { - Damages to other } \\
\text { equipment and surrounding } \\
\text { infrastructures }\end{array}$ & $\begin{array}{l}\text { - Stoppage or cancellation of train } \\
\text { services } \\
\text { - Reduction in braking distance } \\
\text { - Lower driving conditions } \\
\text { - Increase in accidents } \\
\text { - Damages to rolling stock materials } \\
\text { - Accumulation of snow surrounding } \\
\text { railway track thus reduction in speeds. } \\
\text { - Freezing of switches results in } \\
\text { delays } \\
\text { - Reduce in transport quality }\end{array}$ \\
\hline 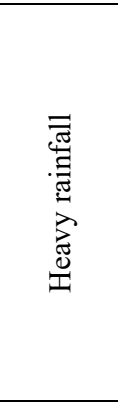 & lo & $\begin{array}{l}- \text { Destruction to railway } \\
\text { embankments and culverts } \\
\text { - Less support to bridge } \\
\text { scour } \\
\text { - Increase in water content } \\
\text { on track } \\
\text { - Destruction to railway } \\
\text { track } \\
\text { - Damages to other } \\
\text { equipment and surrounding } \\
\text { infrastructures }\end{array}$ & $\begin{array}{l}\text { - Stoppage or cancellation of train } \\
\text { services } \\
\text { - Reduction in braking distance } \\
\text { - Lower driving conditions } \\
\text { - Increase in accidents } \\
\text { - Damages to rolling stock materials } \\
\text { - Accumulation of snow surrounding } \\
\text { railway track thus reduction in speeds. } \\
\text { - Freezing of switches results in } \\
\text { delays } \\
\text { - Reduce in transport quality }\end{array}$ \\
\hline  & $\begin{array}{l}\text { - Rise in sea level } \\
\text { - Destruction to power } \\
\text { cables } \\
\text { - Falling of trees } \\
\text { adjacent to railway } \\
\text { track } \\
\text { - Damage to } \\
\text { electricity } \\
\text { - Increase in freezing } \\
\text { - Blockage of tracks }\end{array}$ & $\begin{array}{l}\text { - Destruction to railway } \\
\text { embankments and culverts } \\
\text { - Less support to bridge } \\
\text { scour } \\
\text { - Increase in water content } \\
\text { on track } \\
\text { - Destruction to railway } \\
\text { track } \\
\text { - Damages to other } \\
\text { equipment and surrounding } \\
\text { infrastructures } \\
\text { - Power cable falls }\end{array}$ & $\begin{array}{l}\text { - Stoppage or cancellation of train } \\
\text { services } \\
\text { - Reduction in braking distance } \\
\text { - Lower driving conditions } \\
\text { - Increase in accidents } \\
\text { - Damages to rolling stock materials. } \\
\text { - Accumulation of snow surrounding } \\
\text { railway track thus reduction in speeds. } \\
\text { - Freezing of switches results in } \\
\text { delays } \\
\text { - Reduce in transport quality }\end{array}$ \\
\hline  & $\begin{array}{l}\text { - Destruction to power } \\
\text { cables } \\
\text { - Damage to } \\
\text { electricity } \\
\text { - Increase in freezing. } \\
\text { - Frost }\end{array}$ & $\begin{array}{l}\text { - Burning of safety devices } \\
\text { - Damages to other } \\
\text { equipment and surrounding } \\
\text { infrastructures } \\
\text { - Cracking of Frost } \\
\text { Increased freezing of other } \\
\text { equipment and structures } \\
\text { - Damage to power cables } \\
\text { - Destruction to rail track }\end{array}$ & $\begin{array}{l}\text { - Stoppage or cancellation of train } \\
\text { services } \\
\text { - Reduction in braking distance } \\
\text { - Lower driving conditions } \\
\text { - Increase in accidents. } \\
\text { - Damages to rolling stock materials. } \\
\text { - Accumulation of snow surrounding } \\
\text { railway track thus reduction in speeds. } \\
\text { - Freezing of switches results in } \\
\text { delays } \\
\text { - Reduce in transport quality }\end{array}$ \\
\hline
\end{tabular}




\begin{tabular}{|c|c|c|c|}
\hline 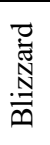 & $\begin{array}{l}\text { - Combination of } \\
\text { lower temperature, } \\
\text { increase in snowfall, } \\
\text { and windstorms }\end{array}$ & $\begin{array}{l}\text { - All the above } \\
\text { consequences excluding } \\
\text { high temperature }\end{array}$ & $\begin{array}{l}\text { - All the above consequences } \\
\text { excluding high temperature }\end{array}$ \\
\hline
\end{tabular}

Table 5. Summary of the impact of extreme weather events on vulnerable assets

\begin{tabular}{|c|c|c|c|c|}
\hline Study & $\begin{array}{l}\text { Extreme weather } \\
\text { events }\end{array}$ & Vulnerable asset & Consequence & Country \\
\hline$[40]$ & $\begin{array}{l}\text { Vegetation due to } \\
\text { snow and rainfall }\end{array}$ & $\begin{array}{c}\text { Earthwork } \\
\text { (Embankment) }\end{array}$ & $\begin{array}{c}\text { Changes in permeability and } \\
\text { plasticity }\end{array}$ & UK \\
\hline$[41]$ & $\begin{array}{l}\text { Low and high } \\
\text { temperatures, rainfall, } \\
\text { and floods }\end{array}$ & $\begin{array}{l}\text { Tracks located in bridge } \\
\text { transition zones }\end{array}$ & Increase in track stiffness & UK \\
\hline \multirow{5}{*}[42]{} & \multirow{5}{*}{ Hot temperature } & $\begin{array}{l}\text { Track buckling and } \\
\text { short-term speed } \\
\text { restrictions }\end{array}$ & $\begin{array}{l}\text { Increase in stress-free } \\
\text { temperature }\end{array}$ & \multirow{5}{*}{ UK } \\
\hline & & Ballast maintenance & Heat expansion of sleepers & \\
\hline & & $\begin{array}{l}\text { Occurrence of sag of the } \\
\text { overhead line equipment } \\
\text { (OLE) }\end{array}$ & $\begin{array}{l}\text { Increase in exceedance of } \\
\text { OLE }\end{array}$ & \\
\hline & & Staff exposure & Increase in personnel stress & \\
\hline & & Freight risk & Overhead line sag & \\
\hline$[43]$ & $\begin{array}{l}\text { Hot temperature and } \\
\text { low humidity }\end{array}$ & $\begin{array}{c}\text { Sleepers in ballasted } \\
\text { track systems }\end{array}$ & Increase in creep coefficient & UK \\
\hline$[44]$ & $\begin{array}{l}\text { Rainfall, sea-level } \\
\text { rise, heat, and cold } \\
\text { snap }\end{array}$ & $\begin{array}{l}\text { Sleepers in ballasted } \\
\text { track }\end{array}$ & $\begin{array}{l}\text { Reduce instability and } \\
\text { increase in ground-borne } \\
\text { vibration }\end{array}$ & UK \\
\hline$[45]$ & $\begin{array}{l}\text { Snow and low } \\
\text { temperature }\end{array}$ & $\begin{array}{c}\text { Railway track and } \\
\text { Switches and crossings }\end{array}$ & Increase in maintenance & Sweden \\
\hline [46] & Permafrost & Embankment & Sand clogging & China \\
\hline \multirow{4}{*}[47]{} & High water content & \multirow{4}{*}{ Turnouts } & Progressive shear failure & \multirow{4}{*}{ UK } \\
\hline & Heavy rains & & Washout & \\
\hline & Deviation in moisture & & Swelling/shrinkage & \\
\hline & $\begin{array}{c}\text { Low temperature } \\
\text { Frost susceptible soil }\end{array}$ & & Frost action & \\
\hline [48] & Permafrost & Track system & Thawing of ground & China \\
\hline$[49]$ & Floods and rainfall & Bridges & $\begin{array}{l}\text { Bridge scour (removal of } \\
\text { riverbed material) }\end{array}$ & UK \\
\hline$[50]$ & $\begin{array}{l}\text { Snow and ice, } \\
\text { rainfall, and low } \\
\text { temperature } \\
\end{array}$ & Switches and crossings, & Signalling failures & Sweden \\
\hline$[51]$ & $\begin{array}{l}\text { Temperatures, } \\
\text { rainfall, permafrost, } \\
\text { and snowfall } \\
\end{array}$ & $\begin{array}{l}\text { Drainage systems, track, } \\
\text { and other infrastructure }\end{array}$ & $\begin{array}{l}\text { Traffic disruption, speed } \\
\text { restrictions, and accidents }\end{array}$ & Austria \\
\hline [52] & Solar storms & Track signalling & Increase in induced currents & Sweden \\
\hline$[53]$ & High temperature & Slab track & $\begin{array}{c}\text { Decrease in fatigue life and } \\
\text { degradation of mortar }\end{array}$ & China \\
\hline$[54]$ & Low humidity & $\begin{array}{l}\text { Sleepers for ballasted } \\
\text { tracks }\end{array}$ & $\begin{array}{c}\text { Elastic shortening, increase } \\
\text { in concrete creep, and } \\
\text { shrinkage }\end{array}$ & Turkey \\
\hline$[55]$ & Floods and rainfall & Metro systems & $\begin{array}{l}\text { Identified potential areas of } \\
\text { flooding }\end{array}$ & Spain \\
\hline$[26]$ & High temperatures & $\begin{array}{l}\text { Ballasted track on the } \\
\text { bridge }\end{array}$ & $\begin{array}{l}\text { Increase in fatigue stress and } \\
\text { decrease in stability }\end{array}$ & Russia \\
\hline$[56]$ & Sea level rise & Railway infrastructure & $\begin{array}{l}\text { Traffic disruption and speed } \\
\text { restrictions }\end{array}$ & UK \\
\hline
\end{tabular}




\begin{tabular}{|c|c|c|c|c|}
\hline$[57]$ & High temperature & Railway track & Buckling effect & Europe \\
\hline$[58]$ & High temperature & Railway track & Stress free temperature & France \\
\hline$[59]$ & High temperature & Railway track & Stress free temperature & $\begin{array}{c}\text { UK \& } \\
\text { Spain }\end{array}$ \\
\hline$[60]$ & Low temperature & Railway track & Freight train delays & Finland \\
\hline$[61]$ & All & Railway infrastructure & Train delays & Italy \\
\hline$[62]$ & Rainfall & Railway embankment & Train delays & Malaysia \\
\hline$[63]$ & Rainfall & Turnouts & Accidents & UK \\
\hline$[25]$ & High temperature & Track geometry & Intervention delays & UK \\
\hline$[64]$ & Permafrost & Embankment & Safety & China \\
\hline$[65]$ & High temperature & Track & Rail buckling & Spain \\
\hline$[66]$ & Rainfall & Railway infrastructure & Costs and disruption & China \\
\hline$[67]$ & $\begin{array}{c}\text { Temperature and } \\
\text { rainfall }\end{array}$ & Railway infrastructure & Disruption & Spain \\
\hline$[68]$ & $\begin{array}{c}\text { Temperature and } \\
\text { rainfall }\end{array}$ & Railway infrastructure & Sand drifts & Iran \\
\hline$[69]$ & Low temperature & Culverts & Accidents & Sweden \\
\hline$[70]$ & Low temperature & Track and turnouts & Train delays & Sweden \\
\hline
\end{tabular}

Furthermore, a suitable early warning system and emergency response system needs to be adapted to monitor trends in climate, detect and predict the effect of extreme weather events, and developing of necessary firefighting guidelines to reduce its impact and rapid recovery from adverse weather events [81]. Swedish Civil Contingencies Agency (MSB) plays this role to prepare for the emergency response and contingency planning to reduce the climatic impacts on railway infrastructure. One such policy development was carried out in Västra Götland [82]. In addition, there is also needed to combine climate models with infrastructure degradation models for quantification of impacts of climate change on railway infrastructure.

\section{Conclusions}

It is evident from the state of the art review that railway infrastructure is vulnerable to extreme weather events due to climate change. Hence, it requires careful planning of operation and maintenance activities to ensure the safety, robustness, and resilience of railway infrastructure. The vulnerable assets identified in Table 5 can also relevant to the Swedish climate. Swedish Portal for climate change adaptation [31] suggested that climate change impacts could severely affect the railway infrastructure in terms of torrential rain, landslides, erosion, and level changes in seas, lakes, and groundwater place new demands.

The variations in temperature, especially for a country like Sweden, necessitate the development of precautionary measures to address the impacts caused by extreme heat and extreme cold wave. For instance, rail buckling, risk of fires in railway corridor, and failure of electronic systems are the main failure modes due to extreme heat wave. In addition, it is identified that increased temperature could also lead to longer vegetation on rail corridors. An increase in winds leads to the presence of leaves on the track and the potential falling of trees adjacent to the tracks. This may necessitate climate adaptation measures for the development of maintenance and inspection procedures [83]. Furthermore, there is also a need to increase efforts for monitoring, identifying, and forecasting increased temperature using various technologies, tools, models, and methods that support the implementation of recommended actions to reduce this impact.

Due to complexity dealing with climatic impacts on railway system, future adaptation setting is based on current climate scenarios and uncertainties and variabilities on both temporal and spatial scale. The existing climate scenarios for regional conditions are quite limited to short-term predictions due to inaccurate global models. This could affect the climate models for the long-term duration as well to pinpoint the susceptible regions in Sweden. For long-term planning, the existing regional climate scenarios are needed to be analyzed in-depth for adaptive measures to 
mitigate the climate change impacts.

Currently, the Swedish railway sector uses frequency and its associated consequences of extreme weather events that are evaluated through historical data and other related information. This practice needs to be implemented for the long-term duration as well to cope with the already degrading infrastructure considering uncertainties. More efforts are needed in other asset infrastructures, such as drainage systems, catenary systems, and vegetation management, to reduce their impact due to climate change.

There is a need to develop a holistic long-term and proactive strategy for climate adaptation of railway infrastructure for the future. Accordingly, European Rail Administrations and other related stakeholders engaged in infrastructure planning has developed following guidelines to address the challenges arising due to extreme weather events [34]:

1) Methodical mapping of different types of climate extreme weather events, their impacts, and vulnerabilities for railway assets need to be carried out first to make the railway more reliable and safer.

2) Climate change needs to be considered during the initial stages of the design and planning process to accommodate risk and vulnerability assessments that are applied in the planning, design, operation, and maintenance process.

3) To conduct further detailed risk and vulnerability analysis, the potential consequences need to assess, methodically evaluated, and suitable methodologies need to be implemented to ensure that the results compensate with the occurrence and severity of events in contradiction to their consequences in an organized way.

4) Risk and vulnerability assessment need not be conducted based on past events alone. An explorative approach needs to be followed considering various well-developed technologies and tools to be implemented in conjunction with the existing methods. Use of Artificial Intelligence (AI) methods to detect, predict, and recommend necessary measures, accommodating both satellite and on-ground monitoring devices, conducting interviews with expert opinions in workshops, etc., to be able to proactive to the uncertain conditions of the future for threats and vulnerable areas of railway transport.

5) While designing or building new infrastructure, climate adaptation measures need to be incorporated so that the effects of extreme weather events can be minimal to the best by developing effective counter-productive measures.

6) Accordingly, there is a necessity to increase knowledge and awareness among the public about potential threats of climate events on railway infrastructure to reduce the unnecessary costs, burden, and discomfort that occurred due to unwarranted disruptions to traffic and other effects.

7) Necessary emergency and contingency plans need to be developed for future climate impacts on the railway infrastructure that could reduce the consequences due to unexpected climate events.

8) From the governmental perspective, the necessary development of policies must be initiated and revision of standards to be encouraged to accommodate the future needs of climate change during entire life cycle phases of railway infrastructure.

Furthermore, the conclusions of this study concerning international literature related to the state of the art facing transportation networks are:

1) Significant diversity of multidisciplinary inputs to assess the effects of climate change on transport networks, and to develop robust adaptation strategies covering the planning, design, operation, and maintenance of such services.

2) Need for climate change factors to be incorporated into infrastructure design and maintenance on an ongoing basis, e.g., by considering climate factors in maintenance modeling and calculation.

3) Value of risk analysis tools to define the thresholds and standards of transport service to guide transport planning, engineering, and future investment to account for the inherent uncertainties with including climate-related factors into the decision-making process.

4) The use of early warning systems in some studies is an important part of minimizing the 
impacts of climate change-related damage and disruption to transport.

\section{Acknowledgements}

Authors would like to thank Swedish Innovation Agency Vinnova, JVTC, Trafikverket, INFRANORD, and Sweco for their financial support to carry out this work within the framework of CliMaint Project (www.ltu.se/climaint).

\section{References}

[1] T. Wang et al., "Impacts of climate change on rail systems," 1st ed., in Safety and Reliability - Safe Societies in a Changing World, CRC Press, 2018, pp. 2771-2779.

[2] G. Love, A. Soares, and H. Püempel, "Climate change, climate variability and transportation," Procedia Environmental Sciences, Vol. 1, pp. 130-145, 2010, https://doi.org/10.1016/j.proenv.2010.09.010

[3] G. Grendstad, "Adaptation to climate change," Project Group on Climate Change. CEDR's Secretariat General, 2012.

[4] N. Stern, The Economics of Climate Change. Cambridge: Cambridge University Press, 2007, https://doi.org/10.1017/cbo9780511817434

[5] H. Maurer et al. "Weather extremes: assessment of impacts on transport systems and hazards for european regions," https://explore.openaire.eu/search/other?orpid=dedup_wf_001:: 206f4851adaaae0fba08b91ec8173536, 2012.

[6] Potential Impacts of Climate Change on U.S. Transportation. Washington, D.C.: Transportation Research Board, 2008, pp. 21-24, https://doi.org/10.17226/12179

[7] M. B. Regmi and S. Hanaoka. "Impacts of climate change on transport and adaptation in Asia," Proceedings of the Eastern Asia Society for Transportation Studies, https://www.jstage.jst.go.jp/article/eastpro/2009/0/2009_0_206/ article/-char/en, 2009.

[8] E. A. Baron, S. Fernandes, J. C. Matos, and H. S. Sousa, "An overview of the project strengthening infrastructure risk management in the Atlantic area (SIRMA)," in Life-Cycle Civil Engineering: Innovation, Theory and Practice, CRC Press, 2021, pp. 1237-1241, https://doi.org/10.1201/9780429343292-164

[9] R. Nolte, C. Kamburow, J. Rupp. R. Nolte, C. Kamburow, and J. Rupp, ARISCC-Adaptation of Railway Infrastructure to Climate Change. Berlin, Germany, 2011.

[10] C. J. Baker, L. Chapman, A. Quinn, and K. Dobney, "Climate change and the railway industry: A review," Proceedings of the Institution of Mechanical Engineers, Part C: Journal of Mechanical Engineering Science, Vol. 224, No. 3, pp. 519-528, Mar. 2010, https://doi.org/10.1243/09544062jmes1558

[11] S. Kaewunruen, J. M. Sussman, and A. Matsumoto, "Grand challenges in transportation and transit systems," Frontiers in Built Environment, Vol. 2, Feb. 2016, https://doi.org/10.3389/fbuil.2016.00004

[12] J. Armstrong, J. Preston, and A. Ortega Hortelano, "Enabling resilient railway operations in the context of climate change," in 7th International Conference on Railway Operations Modelling and Analysis, Congress Center "Lille Grand Palais", 2017.

[13] United Nations Economic Commission for Europe, "Climate Change Impacts and Adaptation for Transport Networks and Nodes," United Nations, Geneva, 2020.

[14] J. E. Thornes and B. W. Davis, "Mitigating the impact of weather and climate on railway operations in the UK," in 2002 ASME/IEEE Joint Railroad Conference, pp. 29-38, 2002, https://doi.org/10.1109/rrcon.2002.1000089

[15] M. J. Koetse and P. Rietveld, "The impact of climate change and weather on transport: An overview of empirical findings," Transportation Research Part D: Transport and Environment, Vol. 14, No. 3, pp. 205-221, May 2009, https://doi.org/10.1016/j.trd.2008.12.004

[16] M. Meyer, Design standards for US transportation infrastructure: The implications of climate change. 2008.

[17] S. Dasgupta, B. Laplante, C. Meisner, D. Wheeler, and J. Yan, "The impact of sea level rise on developing countries: a comparative analysis," Climatic Change, Vol. 93, No. 3-4, pp. 379-388, Apr. 2009, https://doi.org/10.1007/s10584-008-9499-5

[18] A. Mackay, "Climate Change 2007: Impacts, Adaptation and Vulnerability. Contribution of Working Group II to the Fourth Assessment Report of the Intergovernmental Panel on Climate Change," 
Journal of Environmental Quality, Vol. 37, No. 6, pp. 2407-2407, Nov. 2008, https://doi.org/10.2134/jeq2008.0015br

[19] R. Döscher, "Climate extremes for Sweden - State of knowledge and implications for adaptation and mitigation," SMHI, 2019, https://doi.org/10.17200/climate_extremes_sweden

[20] H. Lee, Intergovernmental Panel on Climate Change. $200 \overline{7}$.

[21] R. B. Mallick, M. J. Radzicki, J. S. Daniel, and J. M. Jacobs, "Use of System Dynamics to Understand Long-Term Impact of Climate Change on Pavement Performance and Maintenance Cost," Transportation Research Record: Journal of the Transportation Research Board, Vol. 2455, No. 1, pp. 1-9, Jan. 2014, https://doi.org/10.3141/2455-01

[22] B. Mills and J. Andrey, "Climate change and transportation: potential interactions and impacts," in The Potential Impacts of Climate Change on Transportation, 2003.

[23] D. S. Lemmen and F. J. Warren, Climate Change Impacts and Adaptation: A Canadian Perspective. Natural Resources Canada, Ottawa, Ontario, 2004.

[24] J. Diaz-Nieto and R. L. Wilby, "A comparison of statistical downscaling and climate change factor methods: impacts on low flows in the River Thames, United Kingdom," Climatic Change, Vol. 69, No. 2-3, pp. 245-268, Apr. 2005, https://doi.org/10.1007/s10584-005-1157-6

[25] B. Davies and J. Andrews, "The impact of summer heatwaves on railway track geometry maintenance," Proceedings of the Institution of Mechanical Engineers, Part F: Journal of Rail and Rapid Transit, p. 095440972098429, Jan. 2021, https://doi.org/10.1177/0954409720984292

[26] N. Mirković, Z. Popović, A. Pustovgar, L. Lazarević, and A. Zhuravlev, "Management of stresses in the rails on railway bridges," FME Transactions, Vol. 46, No. 4, pp. 636-643, 2018, https://doi.org/10.5937/fmet1804636m

[27] K. Wright and C. Hogan, The Potential Impacts of Global Sea Level Rise on Transportation Infrastructure: Part 1-Methodology. ICF International, 2008.

[28] R. K. Pachauri et al., Climate Change 2014: Synthesis Report. Contribution of Working Groups I, II and III to the Fifth Assessment Report of the Intergovernmental Panel on Climate Change. 2014.

[29] D. Davour, "Present and Future Extreme Weather in Sweden According to the d4PDF," Master Thesis, Department of Building and Environmental Technology, Lund University, 2019.

[30] C. B. Field et al., Managing the Risks of Extreme Events and Disasters to Advance Climate Change Adaptation. Cambridge: Cambridge University Press, 2012.

[31] Klimatanpassning. "Climate change in Sweden," http://www.klimatanpassning.se/en/climate-changein-sweden (accessed 2021).

[32] T. Koenigk et al., "On the contribution of internal climate variability to European future climate trends," Tellus A: Dynamic Meteorology and Oceanography, Vol. 72, No. 1, pp. 1-17, Jan. 2020, https://doi.org/10.1080/16000870.2020.1788901

[33] A. H. S. Garmabaki et al., "A survey on underground pipelines and railway infrastructure at crosssections," PipeXrail, p. 1094, 2019, https://doi.org/10.3850/978-981-11-2724-3 0037-cd

[34] J. Lindgren, D. K. Jonsson, and A. Carlsson-Kanyama, "Climate adaptation of railways: lessons from Sweden," European Journal of Transport and Infrastructure Research, Vol. 9, p. Vol 9 No 2 (2009), Apr. 2009, https://doi.org/10.18757/ejtir.2009.9.2.3295

[35] B. Holgersson, "Sverige inför klimatförändringarna-hot och möjligheter. Sverige inför klimatförändringarna-hot och möjligheter," 2017.

[36] I. Oslakovic Stipanovic, H. W. T. Maat, A. Hartmann, and G. Dewulf, "Risk assessment of climate change impacts on railway infrastructure," in Engineering Project Organization Conference, 2013.

[37] L. Hawchar, O. Naughton, P. Nolan, M. G. Stewart, and P. C. Ryan, "A GIS-based framework for high-level climate change risk assessment of critical infrastructure," Climate Risk Management, Vol. 29, p. 100235, 2020, https://doi.org/10.1016/j.crm.2020.100235

[38] R. Baltica, "Study on climate change impact assessment for the design, construction, maintenance and operation of rail baltica railway," 2019.

[39] R. Pant, J. W. Hall, and S. P. Blainey, "Vulnerability assessment framework for interdependent critical infrastructures: case-study for Great Britain's rail network," European Journal of Transport and Infrastructure Research, Vol. 16, 2016, https://doi.org/10.18757/ejtir.2016.16.1.3120

[40] J. Scott, F. Loveridge, and A. S. O. Brien, "Influence of climate and vegetation on railway embankments," in 14th European Conference on Soil Mechanics and Geotechnical Engineering, 2007.

[41] S. Setsobhonkul, S. Kaewunruen, and J. M. Sussman, "Lifecycle assessments of railway bridge transitions exposed to extreme climate events," Frontiers in Built Environment, Vol. 3, p. 35, Jun. 2017, https://doi.org/10.3389/fbuil.2017.00035 
[42] E. J. Palin, H. E. Thornton, C. T. Mathison, R. E. Mccarthy, R. T. Clark, and J. Dora, "Future projections of temperature-related climate change impacts on the railway network of Great Britain," Climatic Change, Vol. 120, No. 1-2, pp. 71-93, Sep. 2013, https://doi.org/10.1007/s10584-013-0810-8

[43] D. Li and S. Kaewunruen, "Effect of extreme climate on topology of railway prestressed concrete sleepers," Climate, Vol. 7, No. 1, p. 17, Jan. 2019, https://doi.org/10.3390/cli7010017

[44] S. Kaewunruen, L. C. Lopes, and M. P. Papaelias, "Georisks in railway systems under climate uncertainties by different types of sleeper/crosstie materials," Lowland Technology International, Vol. 20, pp. 77-86, 2018.

[45] C. Stenström et al., "Impact of cold climate on failures in railway infrastructure," in International Conference on Maintenance Performance Measurement and Management, 2012.

[46] L. Chen, W. Yu, X. Yi, D. Hu, and W. Liu, "Numerical simulation of heat transfer of the crushed-rock interlayer embankment of Qinghai-Tibet Railway affected by aeolian sand clogging and climate change," Cold Regions Science and Technology, Vol. 155, pp. 1-10, Nov. 2018, https://doi.org/10.1016/j.coldregions.2018.07.009

[47] S. Dindar, S. Kaewunruen, and J. M. Sussman, "Climate change adaptation for georisks mitigation of railway turnout systems,” Procedia Engineering, Vol. 189, pp. 199-206, 2017, https://doi.org/10.1016/j.proeng.2017.05.032

[48] Qingbai Wu, Shuxun Li, and Yongzhi Liu, "The impact of climate warming on permafrost and Qinghai-Tibet Railway,” Engineering Sciences, Vol. 4, No. 2, pp. 92-97, 2006.

[49] H. Dikanski, A. Hagen-Zanker, B. Imam, and K. Avery, "Climate change impacts on railway structures: bridge scour," Proceedings of the Institution of Civil Engineers - Engineering Sustainability, Jun. 2016, https://doi.org/10.1680/jensu.15.00021

[50] U. Juntti, Impact of climate on railway operation: a Swedish case study, 2012.

[51] P. Kellermann, P. Bubeck, G. Kundela, A. Dosio, and A. Thieken, "Frequency analysis of critical meteorological conditions in a changing climate-assessing future implications for railway transportation in Austria," Climate, Vol. 4, No. 2, p. 25, Apr. 2016, https://doi.org/10.3390/cli4020025

[52] A. Thaduri, D. Galar, and U. Kumar, "Space weather climate impacts on railway infrastructure," International Journal of System Assurance Engineering and Management, Vol. 11, No. S2, pp. 267281, Jul. 2020, https://doi.org/10.1007/s13198-020-01003-9

[53] N. Wang, D. Satola, A. Houlihan Wiberg, C. Liu, and A. Gustavsen, "Reduction strategies for greenhouse gas emissions from high-speed railway station buildings in a cold climate zone of China," Sustainability, Vol. 12, No. 5, p. 1704, Feb. 2020, https://doi.org/10.3390/su12051704

[54] N. Bezgin, "Climate effects on the shoulder width measurements of prestressed concrete high speed railway sleepers of ballasted tracks," Measurement, Vol. 75, pp. 201-209, Nov. 2015, https://doi.org/10.1016/j.measurement.2015.07.057

[55] E. Forero-Ortiz, E. Martínez-Gomariz, M. Cañas Porcuna, L. Locatelli, and B. Russo, "flood risk assessment in an underground railway system under the impact of climate change-a case study of the Barcelona metro," Sustainability, Vol. 12, No. 13, p. 5291, Jun. 2020, https://doi.org/10.3390/su12135291

[56] D. A. Dawson, A. Hunt, J. Shaw, and W. R. Gehrels, "The economic value of climate information in adaptation decisions: learning in the sea-level rise and coastal infrastructure context," Ecological Economics, Vol. 150, pp. 1-10, Aug. 2018, https://doi.org/10.1016/j.ecolecon.2018.03.027

[57] R. Nemfrancoise and E. Demirhande, "Impacts of climate change on transport: a focus on road and rail transport infrastructures," Publications Office of the European Union, 2012.

[58] L. Girardi, D. Boulanger, E. Laurans, P. Pouligny, Y. Xu, and J. Colibri, "Rail temperature forecasts over different time-ranges for track applications," in 5th IET Conference on Railway Condition Monitoring and Non-Destructive Testing (RCM 2011), 2011, https://doi.org/10.1049/cp.2011.0609

[59] K. Dobney, "Quantifying the effects of an increasingly warmer climate with a view to improving the resilience of Great Britain's railway network: is a new stressing regime the answer?" Doctor of Philosophy, The University of Birmingham, 2010.

[60] J. Ludvigsen and R. Klæboe, "Extreme weather impacts on freight railways in Europe," Natural Hazards, Vol. 70, No. 1, pp. 767-787, Jan. 2014, https://doi.org/10.1007/s11069-013-0851-3

[61] L. Oneto et al., "Advanced analytics for train delay prediction systems by including exogenous weather data," in 2016 IEEE International Conference on Data Science and Advanced Analytics (DSAA), pp. 458-467, Oct. 2016, https://doi.org/10.1109/dsaa.2016.57

[62] M. J. Roshan, A. S. A. Rashid, N. A. Wahab, M. A. Hezmi, S. N. Jusoh, and M. Azmi, "Stability of railway embankment in saturated and unsaturated conditions," IOP Conference Series: Materials 
Science and Engineering, Vol. 1153, No. 1, p. 012007, May 2021, https://doi.org/10.1088/1757$899 x / 1153 / 1 / 012007$

[63] M. Hamarat, M. Papaelias, and S. Kaewunruen, "Vulnerability of railway switches and crossings exposed to flooding conditions," in Virtual Conference on Disaster Risk Reduction, 2021.

[64] C.-X. Tang, Z.-Y. Zhu, F. Luo, Z.-H. He, Z.-Y. Zou, and Z.-H. Guo, "Deformation behaviour and influence mechanism of thaw consolidation of embankments on the Qinghai-Tibet Railway in permafrost regions," Transportation Geotechnics, Vol. 28, p. 100513, May 2021, https://doi.org/10.1016/j.trgeo.2021.100513

[65] I. Villalba Sanchis, R. Insa Franco, P. Martínez Fernández, P. Salvador Zuriaga, and J. B. Font Torres, "Risk of increasing temperature due to climate change on high-speed rail network in Spain," Transportation Research Part D: Transport and Environment, Vol. 82, p. 102312, May 2020, https://doi.org/10.1016/j.trd.2020.102312

[66] K. Liu, M. Wang, and T. Zhou, "Increasing costs to Chinese railway infrastructure by extreme precipitation in a warmer world," Transportation Research Part D: Transport and Environment, Vol. 93, p. 102797, Apr. 2021, https://doi.org/10.1016/j.trd.2021.102797

[67] E. Ortega, B. Martín, and Aparicio, "Identification of critical sections of the Spanish transport system due to climate scenarios," Journal of Transport Geography, Vol. 84, p. 102691, Apr. 2020, https://doi.org/10.1016/j.jtrangeo.2020.102691

[68] M. R. Rahdari, Y. Gyasi-Agyei, and J. Rodrigo-Comino, "Sand drift potential impacts within desert railway corridors: a case study of the Sarakhs-Mashhad railway line," Arabian Journal of Geosciences, Vol. 14, No. 9, May 2021, https://doi.org/10.1007/s12517-021-07171-7

[69] K. Tommik et al., "Distribution of temperature in culverts in cold climate," 2020.

[70] A. Thaduri, "Nowcast models for train delays based on the railway network status," International Journal of System Assurance Engineering and Management, Vol. 11, No. S2, pp. 184-195, Jul. 2020 , https://doi.org/10.1007/s13198-020-01002-w

[71] L.-G. Mattsson and E. Jenelius, "Vulnerability and resilience of transport systems - A discussion of recent research," Transportation Research Part A: Policy and Practice, Vol. 81, pp. 16-34, Nov. 2015, https://doi.org/10.1016/j.tra.2015.06.002

[72] M. Maibach, D. Bertmann-Aeppli, and M. Peter, "Vulnerability and adaptation strategies in alpine road and rail transport-Swiss case study," Report from the International Panel of Weather, 2012.

[73] V. Dépoues, "Organisational uptake of scientific information about climate change by infrastructure managers: the case of adaptation of the French railway company," Climatic Change, Vol. 143, No. 34, pp. 473-486, Aug. 2017, https://doi.org/10.1007/s10584-017-2016-y

[74] M. Rotter, E. Hoffmann, A. Pechan, and R. Stecker, "Competing priorities: how actors and institutions influence adaptation of the German railway system," Climatic Change, Vol. 137, No. 3-4, pp. 609623, Aug. 2016, https://doi.org/10.1007/s10584-016-1702-5

[75] J. Lane and J. Dora, "Tomorrow's railway and climate change adaptation (TraCCA)," in The 9th World Congress on Railway Research WCRR 2011, 2011.

[76] A. Garg, P. R. Shukla, and M. Kapshe, "From climate change impacts to adaptation: A development perspective for India," Natural Resources Forum, Vol. 31, No. 2, pp. 132-141, May 2007, https://doi.org/10.1111/j.1477-8947.2007.00142.x

[77] J. Daron, "Challenges in using a robust decision making approach to guide climate change adaptation in South Africa," Climatic Change, Vol. 132, No. 3, pp. 459-473, Oct. 2015, https://doi.org/10.1007/s10584-014-1242-9

[78] J. Boyle, M. Cunningham, and J. Dekens, "Climate Change Adaptation and Canadian Infrastructure: A Review of the Literature," IISD, 2013.

[79] E. A. Kostianaia, A. G. Kostianoy, M. A. Scheglov, A. I. Karelov, and A. S. Vasileisky, "Impact of regional climate change on the infrastructure and operability of railway transport," Transport and Telecommunication Journal, Vol. 22, No. 2, pp. 183-195, Apr. 2021, https://doi.org/10.2478/ttj-20210014

[80] E. Liljegren, "Regeringsuppdrag om Trafikverkets klimatanpassningsarbete," 2019.

[81] H.-P. Berg, "Risks and consequences of weather hazards on railway infrastructure," Journal of Polish Safety and Reliability Association Summer Safety and Reliability Seminar, Vol. 8, No. 1, pp. 1-12, 2017.

[82] E. C. H. Keskitalo, "Adapting to climate change in Sweden: national policy development and adaptation measures in Västra Götaland," in Developing Adaptation Policy and Practice in Europe: 
Multi-level Governance of Climate Change, Dordrecht: Springer Netherlands, 2010, pp. 189-232, https://doi.org/10.1007/978-90-481-9325-7_5

[83] J. Lindgren, D. K. Jonsson, and A. Carlsson-Kanyama, "Climate adaptation of railways: lessons from Sweden," European Journal of Transport and Infrastructure Research, Vol. 9, No. 2, 2009.

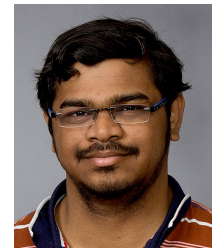

Adithya Thaduri is Associate professor in Division of Operation and Maintenance Engineering at Luleå University of Technology (LTU). His areas of research are on diagnostics and prognostics, degradation modelling, maintenance decision support systems in railway infrastructure and mining equipment. He has worked on several EU Projects; INFRALERT, IN2Smart, IN2Rail, Fr8Rail, projects on Railway, mining, and aircraft for national projects such as CliMaint, SIMTRACK, MINDI, NFFP6, PipeXRail relates to reliability, maintenance, data analytics and decision support.

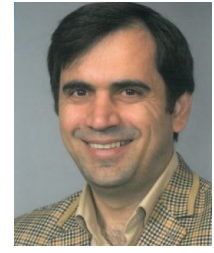

Amir Garmabaki has Ph.D. in reliability and maintenance, and he is and expert in data analytics. He has participated in several projects as project leader and researcher. Amir's main interests revolve around optimization \& statistical data analytics aspects of reliability, maintenance modeling, remaining useful life estimation, and cost modeling of transport Infrastructure. Amir has also been involved in several infrastructure projects as principal investigators, for instance, INFRALERT (EU), PipeXrail, CliMaint, etc. related to the condition assessment of the infrastructure.

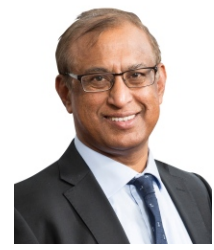

Uday Kumar is the Chair Professor of Operation and Maintenance Engineering and Director of Luleå Railway Research Center at LTU. He has more than 30 years of experiences in research, consulting and finding solutions to industrial problems directly or indirectly related to reliability and maintenance of engineering systems. 